\title{
Kandungan Energi Bruto, Energi Tercerna dan Energi Metabolis Pakan Cair Fermentasi Berbahan Biji Asam Utuh pada Babi Grower
}

\section{Gross Energy Content and Prediction of Digestible Energy and Metabolic Energy of Tamarind Seed Liquid Feed Fermentation of Pig Grower}

\section{Redempta Wea ${ }^{1) *}$, Bernadete B. Koten ${ }^{2)}$, Christian A. Morelaka ${ }^{2)}$}

${ }^{1)}$ Program Studi Produksi Ternak/Jurusan Peternakan Politeknik Pertanian Negeri Kupang, Jl. Prof. Dr. Herman Yohanes, Lasiana, Kupang

${ }^{2}$ Program Studi Teknologi Pakan Ternak/Jurusan Peternakan Politeknik Pertanian Negeri Kupang, Jl. Prof. Dr. Herman Yohanes, Lasiana, Kupang

Article history

Received: Oct 13, 2020;

Accepted: May 23, 2021

* Corresponding author:

E-mail:

redemptawea136@gmail.com

DOI:

10.46549/jipvet.v11i2. 156

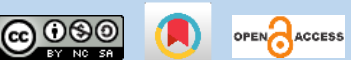

Abstract

Tamarind seeds have a high energy content but have limited use for pigs because the seed coat is tough and contains anti-nutrient tannins. Therefore, liquid feed fermentation technology is carried out. The aim of this research was to assess the gross energy, digestible energy and metabolizable energy content of liquid feed fermentation (Lff) with different fermentation time in growing pigs. The research materials were whole tamarind seeds, bran, corn, meat and bone meal, and soybean meal. The study used a completely randomized design and consisted of 5 treatments and 5 replications. Treatment $=$ Lf0: Lff time 0 days; Lf1: Lff for 7 days, Lf2: Lff for 14 days, Lf3: Lff for 21days, Lf4: Lff for 28 days fermentation. The research variables were the energy content of the ration and the prediction of digestible energy and metabolic energy value. Data were analyzed using analysis of variance and Duncan's advanced test. The results showed that the fermentation of liquid feed containing tamarind seeds with different fermentation time had a significant effect $(\mathrm{P}<0.05)$ on the gross energy content, digestible energy, and metabolic energy. The best gross energy content, digestible energy, and metabolic energy at the fermentation time of 14 days, respectively $4,835 \pm 64.74 \mathrm{Kcal} / \mathrm{kg}$, $3.041 \pm 99.16 \mathrm{Kcal} / \mathrm{kg}$, and $2,974 \pm 99.60 \mathrm{Kcal} / \mathrm{kg}$. It was concluded that the time for fermentation of liquid feed containing tamarind seeds which can produce good energy content and prediction of digestibility and metabolic energy is 14 days.

Keywords: Fiber fraction; Pig grower; Proximate; Tannin

\section{Abstrak}

Biji asam memiliki kandungan energi tinggi namun memiliki keterbatasan penggunaan bagi ternak babi karena kulit biji yang keras dan mengandung anti nutrien tanin. Oleh karena itu dilakukan teknologi fermentasi pakan cair. Tujuan penelitian adalah mengkaji kandungan energi bruto ransum dan memprediksi energi tercerna dan energi metabolis dengan lama fermentasi berbeda pada ternak babi pertumbuhan. Bahan penelitian adalah biji asam utuh, dedak, jagung, tepung daging dan tulang, dan bungkil kacang kedelai. Penelitian menggunakan rancangan acak lengkap dan terdiri dari 5 perlakuan dan 5 ulangan. Perlakuan PC0 : PC lama fermentasi 0 hari; PC1 : PC lama fermentasi 7 hari, R2 : PC lama fermentasi 14 hari, R3 : PC lama fermentasi 21 hari, R4 : PC lama fermentasi 28 hari. Variabel penelitian adalah kandungan energi bruto, prediksi nilai energi tercerna, dan prediksi nilai energi metabolis. Data dianalisis menggunakan analisis varians dan uji lanjut Duncan. Hasil penelitian menunjukkan bahwa fermentasi pakan cair berbahan biji asam dengan lama fermentasi berbeda, berpengaruh nyata $(\mathrm{P}<0,05)$ terhadap kandungan energi bruto, energi tercerna, dan energi metabolis. 
Kandungan energi bruto, energi tercerna, dan energi metabolis terbaik pada lama waktu fermentasi 14 hari, masing-masing 4.835 $\pm 64,74 \mathrm{Kkal} / \mathrm{kg}, 3.041 \pm 99,16$ $\mathrm{Kkal} / \mathrm{kg}$, dan 2.974 $\pm 99,60 \mathrm{Kkal} / \mathrm{kg}$. Disimpulkan bahwa lama fermentasi pakan cair berbahan biji asam yang dapat menghasilkan kandungan energi dan prediksi energi tercerna dan energi metabolime yang baik adalah 14 hari.

Kata kunci: Babi grower; Fraksi serat; Proksimat; Tanin

\section{PENDAHULUAN}

Biji asam merupakan hasil pengolahan industri daging buah asam sebagai bahan pakan sumber energi terutama bagi ternak babi. Biji asam juga merupakan salah satu bahan pakan inkonvensional yang mengandung $92,19 \%$ bahan kering, 14,93\% protein kasar, 6,75\% serat kasar, 5,58\% lemak kasar, 2,93\% abu, $0,41 \%$ kalsium, $0,07 \%$ fosfor, dan 5400 $\mathrm{Kkal} / \mathrm{kg}$ energi (Wea, 2019).

Biji asam sering dimanfaatkan oleh peternak babi di daerah Nusa Tengara Timur (NTT) sebagai bahan pakan sumber energi bagi ternak babi yang diberikan dengan cara dicampur dengan bahan pakan lain maupun diberikan sebagai pakan tunggal. Salah satu keterbatasan penggunaan biji asam bagi ternak babi adalah kulit biji yang keras dan mengandung anti nutrisi tanin yakni 2,47\% (Wea, 2019). Tanin merupakan komponen zat organik yang sangat kompleks, terdiri dari senyawa fenolik yang sukar dipisahkan dan sukar mengkristal, mengendapkan protein dari larutannya dan bersenyawa dengan protein tersebut (Desmiaty et al., 2008). Tannin tergolong senyawa polifenol dengan karakteristiknya yang dapat membentuk senyawa kompleks dengan makromolekul lainnya sehingga tidak mudah dicerna (Westendarp, 2006). Oleh karena itu dibutuhkan teknologi pengolahan, salah satunya adalah pakan cair. Hal ini dikarenakan pencampuran dengan air, bakteri asam laktat, dan jamur alam terjadi dalam proliferasi pakan dan produksi asam laktat, asam asetat, dan ethanol dapat menurunkan $\mathrm{pH}$ campuran sehingga dapat menurunkan $\mathrm{pH}$ dalam saluran pencernaan ternak babi serta tahan dari proliferasi patoghen seperti coliforms dan salmonella (Missotten et al., 2015).

Pengolahan dengan cara melakukan fermentasi pakan cair berbahan biji asam merupakan salah satu solusi yang diterapkan. Fermentasi merupakan teknologi pengolahan pakan dengan menggunakan jasa mikroorganisme yang akan menghasilkan enzim untuk mencerna kandungan nutirien substrat sehingga lebih mudah untuk dimanfaatkan.

Hasil penelitian Wea et al. (2020) menunjukkan bahwa pengolahan biji asam dengan menggunakan teknologi pakan cair bersama dengan bahan pakan lainnya belum menghasilkan perubahan pada kandungan protein kasar, serat kasar, lemak kasar, BETN, dan abu. Lebih lanjut dinyatakan bahwa perbandingan air terbaik pakan cair tersebut adalah 1:3. Hal ini diduga karena lama fermentasi yang singkat yakni \pm 72 jam. Oleh karena itu dilakukan penelitian lanjutan tentang lama fermentasi pakan cair berbahan biji asam dengan perbandingan bahan dengan air adalah 1:3. Teknologi fermentasi pakan cair yang dilakukan ini diharapkan akan berdampak pada nutrien terutama kandungan energi bruto, energi tercerna dan energi metabolis menjadi lebih tersedia. Tujuan penelitian ini adalah mengkaji kandungan energi bruto ransum dan memprediksi energi tercerna dan energi metabolis fermentasi pakan cair berbahan biji asam utuh dengan lama fermentasi berbeda pada ternak babi pertumbuhan. Penelitian ini diharapkan bermanfaat bagi petani peternak agar dapat memanfaatkan biji asam yang dianggap limbah sebagai pakan ternak babi dengan cara fermentasi pakan cair dengan bahan pakan lain agar dapat menghasilkan pertumbuhan ternak babi yang baik jika diberikan sebagai pakan.

\section{MATERI DAN METODE}

Bahan penelitian berupa biji asam utuh, tepung jagung kuning, dedak padi, tepung tulang dan daging, bungkil kedelai, dan air. Perbandingan air pakan cair yakni 1:3 (Wea et 
$a l ;, 2020)$. Perlakuan yang dicobakan terdiri dari : PC0 : Pakan cair lama fermetasi 0 hari; PC1 : Pakan cair lama fermentasi 7 hari; PC2 : Pakan cair lama fermentasi 14 hari; PC3 : Pakan cair lama fermentasi 21 hari; dan PC4 : Pakan cair lama fermentasi 28 hari.

Penelitian menggunakan Rancangan Acak Lengkap dengan lima ulangan sehingga terdapat 25 unit percobaan. Komposisi nutrisi bahan pakan yang digunakan sesuai dengan Standar Nasional Indonesia untuk babi pembesaran (grower) (yakni, kadar air maksimal $14 \%$, protein kasar minimal $15 \%$, lemak kasar maksimal 7\%, serat kasar maksimla 7\%, abu maksimal 8\%, kalsium 0,90$1,20 \%$, fosfor total $0,60-1,00$, energi metabolis minimal $2900 \mathrm{kkal} / \mathrm{kg}$ (Badan Standardisasi Nasional, 2016).

Prosedur penelitian adalah persiapan alat dan bahan, pengumpulan biji asam dari daerah
Timor Tengah Selatan (TTS), penyortiran terhadap benda-benda asing, uji apung (biji asam yang baik adalah yang tenggelam), penimbangan biji asam dan bahan pakan lainnya sesuai perlakuan, pencampuran pakan, pengukuran air sesuai perbandingan, pencampuran air dengan bahan pakan lain, dan fermentasi sesuai perlakuan.

Variabel penelitian berupa kandungan energi bruto (hasil analisa laboratorium), energi tercerna, dan energi metabolis pakan cair (prediksi menggunakan rumus). Data penelitian dianalisis dengan analisis varians dan dilanjutkan dengan uji Jarak Berganda Duncan (Gomez dan Gomez, 2010). Rumus menghitung energi tercerna atau digestible energy (DE) (May and Bell, 1971) dan energi metabolis atau metabolis energy (ME) (Noblet and Perez , 1993) untuk ternak babi, sebagai berikut:

\section{$\mathrm{DE}=4,151+(122 \times \%$ Ash $)+(23 \times \%$ Crude protein $)+(38 \times \%$ Extract eter $)+(64 \times \%$ crude fiber $)$ $\mathrm{ME}=$ Digestible energy $\times(1,012-(0,0019 \times \%$ crude protein $)$}

\section{HASIL DAN PEMBAHASAN}

Biji asam dalam ransum merupakan salah satu bahan pakan inkonvesional sumber energi. Dinyatakan demikian karena biji asam utuh mengandung energi $5140 \pm 18,52 \mathrm{Kkal} / \mathrm{kg}$ (Wea et al., 2019). Kandungan energi bruto dan prediksi energi tercerna dan energi metabolis pakan cair berbahan biji asam untuk ternak babi disajikan pada Tabel 1 .

Tabel 1. Kandungan energi pakan cair berbahan biji asam dengan lama fermentasi berbeda pada ternak babi pertumbuhan $(\mathrm{Kkal} / \mathrm{kg})$

\begin{tabular}{cccc}
\hline Perlakuan & \multicolumn{3}{c}{ Kandungan Energi } \\
\cline { 2 - 4 } & $\begin{array}{c}\text { Energi Bruto (hasil } \\
\text { analisa laboratorium) } \\
\text { Kkal/kg }\end{array}$ & $\begin{array}{c}\text { Energi Tercerna } \\
\text { (Prediksi) Kkal/kg }\end{array}$ & $\begin{array}{c}\text { Energi Metabolis } \\
\text { (Prediksi) Kkal/kg }\end{array}$ \\
\hline PC0 & $4.783 \pm 18,47^{\mathrm{bc}}$ & $2.922 \pm 72,54^{\mathrm{ab}}$ & $2.861 \pm 70,31^{\mathrm{ab}}$ \\
PC1 & $4.880 \pm 60,51^{\mathrm{a}}$ & $2.920 \pm 162,71^{\mathrm{ab}}$ & $2.857 \pm 159,77^{\mathrm{ab}}$ \\
PC2 & $4.835 \pm 64,74^{\mathrm{ab}}$ & $3.041 \pm 99,16^{\mathrm{a}}$ & $2.974 \pm 99,60^{\mathrm{a}}$ \\
PC3 & $4.818 \pm 62,52^{\mathrm{ab}}$ & $2.829 \pm 66,23^{\mathrm{b}}$ & $2.767 \pm 65,92^{\mathrm{b}}$ \\
PC4 & $4.709 \pm 91,08^{\mathrm{c}}$ & $2.868 \pm 183,21^{\mathrm{ab}}$ & $2.808 \pm 180,68^{\mathrm{ab}}$ \\
\hline
\end{tabular}

Keterangan: a,b, c, Superscript yang berbeda pada kolom yang sama menunjukkan perbedaan nyata $(\mathrm{P}>0,05)$; BETN = Bahan Ekstrak Tanpa Nitrogen; PC0 : Pakan cair lama fermentasi 0 hari; PC1 : Pakan cair lama fermentasi 7 hari, PC2 : Pakan cair lama fermentasi 14 hari, PC3 : Pakan cair lama fermentasi 21 hari, PC4 : Pakan cair lama fermentasi 28 hari.

Energi bruto disebut juga gross energy merupakan energi yang dikonsumsi oleh ternak yang terkandung dalam pakan (Sumadi, 2017). Berdasarkan data pada Tabel 1, hasil analisis varians menggambarkan bahwa lama fermentasi pakan cair berbahan biji asam berpengaruh nyata $(\mathrm{P}<0,05)$ terhadap kandungan energi bruto pakan. Hasil uji lanjut Duncan menunjukkan bahwa tidak terdapat perbedaan nyata $(\mathrm{P}>0,05)$ antara pakan cair 
dengan lama fermentasi 0 hari dengan lama fermentasi 14 hari, 21 hari, dan 28 hari, namun berbeda $(\mathrm{P}<0,05)$ kandungan energi bruto pakan cair dengan lama fermentasi 7 hari. Demikian juga tidak terdapat perbedaan $(\mathrm{P}>0,05)$ kandungan energi bruto antara pakan cair lama fermentasi 7 hari dengan lama fermentasi 14 dan 21 hari namun berbeda nyata $(\mathrm{P}<0,05)$ dengan lama fermentasi 28 hari.

Hal ini dikarenakan lama fermentasi 0 hari belum terjadi fermentasi dan kandungan energi bruto tersebut merupakan kandungan dari pakan sendiri tanpa ada aktifitas mikroorganisme sedangkan lama fermentasi 7 hari sudah terjadi aktifitas mikroorganisme secara spontan. Fermentasi spontan atau tanpa menggunakan fermentor maupun menggunakan bahan karbohidrat terlarut air akan menghasilkan bakteri asam laktat (BAL) epifit yang memfermentasi karbohidrat dalam tanaman menjadi asam laktat dan sebagian kecil asam asetat yang akan menurunkan $\mathrm{pH}$ substrat yang akan menghambat perkembangan mikroorganisme patogen (Despal et al., 2011). Demikian selanjutnya fermentasi terus berlangsung oleh kerja mikroorganisme yang mengurai bahan kompleks dalam substrat menjadi sederhana hingga lama fermentasi 28 hari. Bahan kompleks atau makromolekul yang tadinya relatif kompak menjadi agak berporous karena terpecah menjadi molekul sederhana berbobot massa kecil sehingga agak renggang dan lebih mudah menyerap air (Aini et al., 2016).

Menurut Azizah et al. (2012), substrat merupakan bahan baku fermentasi yang mengandung nutrien-nutrien yang dibutuhkan oleh mikroba untuk tumbuh maupun menghasilkan produk fermentasi dan nutrien yang paling dibutuhkan oleh mikroba baik untuk tumbuh maupun untuk menghasilkan produk fermentasi adalah karbohidrat. Lebih lanjut dinyatakan bahwa karbohidrat merupakan sumber karbon yang berfungsi sebagai penghasil energi bagi mikroba, sedangkan nutrien lain seperti protein dibutuhkan dalam jumlah lebih sedikit daripada karbohidrat.

Berdasarkan data pada Tabel 1 menunjukkan bahwa semakin lama waktu fermentasi maka kandungan energi bruto meningkat pada lama fermentasi hingga 21 hari, namun jika lama fermentasi ditingkatkan hingga 28 hari mengalami penurunan. Hal ini memberi gambaran bahwa selama fermentasi berlangsung terjadi peningkatan total mikroba yang didominasi oleh BAL (Hartawan, 2007). Mikroba tersebut mengandung protein kasar sebagai sumber energi. Makin banyak mikroba yang aktif dalam fermentasi berarti semakin tinggi jumlah protein kasar yang akan berdampak pada tingginya kandungan energi bruto pakan. Jika lama fermentasi ditingkatkan ke 28 hari maka terjadi penurunan jumlah mikroba yang aktif sebagai akibat dari berkurangnya substrat yang digunakan sebagai sumber energi bagi mikroba tersebut. Hal ini berdampak pada jumlah protein mikroba yang menjadi bahan pembentuk kandungan energi.

Energi bruto yang terkandung dalam pakan yang dikonsumsi dan dicerna dalam tubuh ternak setelah dikurangi energi dalam feces merupakan energi tercerna (Sumadi, 2017). Hasil analisis varians data pada Tabel 1 menunjukkan bahwa lama fermentasi pakan cair yang mengandung biji asam berpengaruh nyata $(\mathrm{P}<0,05)$ terhadap kandungan energi tercerna. Hasil uji lanjut Duncan menunjukkkan bahwa tidak terdapat perbedaan $(\mathrm{P}>0,05)$ kandungan energi tercerna antara pakan cair lama fermentasi 0 hari dengan lama fermentasi 7 hari, 14 hari dan 28 hari, namun berbeda $(\mathrm{P}<0,05)$ dengan pakan cair lama fermentasi 21 hari. Demikian halnya tidak terdapat perbedaan $(\mathrm{P}>0,05)$ kandungan energi tercerna antara pakan cair lama fermentasi 0 hari dengan lama fermentasi 7 hari, 21 hari dan 28 hari, namun berbeda $(\mathrm{P}<0,05)$ dengan pakan cair lama fermentasi 14 hari. Berdasarkan Tabel 1 juga diketahui bahwa energi tercerna mengalami peningkatan hingga lama fermentasi 14 hari dan jika lama fermentasi diperpanjang hingga 21 dan 28 hari mengalami penurunan.

Hal ini dikarenakan pada lama fermentasi hingga 14 hari masih cukup tersedia karbohidrat mudah larut, protein, dan lemak dalam substrat yang akan dirombak menjadi energi tercerna. Dengan meningkatnya lama fermentasi hingga 21 hari dan 28 hari ketersediaan substrat tersebut menjadi berkurang akibat telah digunakan oleh mikroba. Kondisi ini menyebabkan energi tercerna pakan cair menjadi berkurang. Hal ini juga 
menunjukkan bahwa pakan yang dikonsumsi dengan nilai energi bruto yang berbeda dapat dicerna dengan baik oleh ternak babi grower sehingga nilai energi tercerna setelah sebagian energi terbuang melalui feces adalah sama. Demikian juga ternak babi mampu menggunakan energi bruto dalam pakan cair yang dikonsumsi yang berasal dari karbohidrat, lemak, dan protein (Sumadi, 2007).

Disamping itu, pakan yang mengandung biji asam tersebut diolah dengan menggunakan perbandingan air 1:3 yang menyebabkan keseluruhan pakan dalam keadaan terendam. Hal ini mengakibatkan terjadinya pelunakan pakan maupun kulit biji asam yang menyebabkan terjadinya imbibisi air ke dalam sel. Keadaan ini mempermudah kerja mikroorganisme untuk menghasilkan enzim guna mengurai nutrien kompleks menjadi sederhana. Hal ini dikarenakan semakin lama waktu fermentasi maka mikrroganisme akan semakin aktif berkembang dan melakukan metabolisme (Lestari et al, 2018). Dinyatakan demikian karena tidak dipungkiri bahwa salah satu bahan pakan penyusun pakan cair adalah biji asam yang memilki kulit biji yang keras dan zat anti nutrisi tanin. Zat anti nutrisi tanin terletak banyak di kulit biji, yakni $\pm 56,2 \mathrm{~g} / \mathrm{kg}$ (Panigrahi et al., 1989).

Berdasarkan Tabel 1 diketahui bahwa energi metabolis mengalami peningkatan hingga lama fermentasi 14 hari dan jika lama fermentasi diperpanjang hingga 21 dan 28 hari mengalami penurunan seperti halnya pada energi tercerna. Hasil analisis varians menunjukkan bahwa lama fermentasi pakan cair berpengaruh nyata $(\mathrm{P}<0,05)$ terhadap energi metabolis. Uji Duncan menunjukkan bahwa tidak terdapat perbedaan $(\mathrm{P}>0,05)$ energi metabolis antara pakan cair lama fermentasi 0 hari dengan lama fermentasi 7 hari, 14 hari dan 28 hari, namun berbeda $(\mathrm{P}<0,05)$ dengan pakan cair lama fermentasi 21 hari. Demikian halnya tidak terdapat perbedaan $(\mathrm{P}>0,05)$ energi metabolis antara pakan cair lama fermentasi 0 hari dengan lama fermentasi 7 hari, 21 hari dan 28 hari, namun berbeda $(\mathrm{P}<0,05)$ dengan pakan cair lama fermentasi 14 hari. Hal ini menunjukkan bahwa dengan lama fermentasi 14 hari sudah mampu menghasilkan energi tercerna dan energi metabolis pakan cair berbahan biji asam yang baik.

Kenyataan ini dikarenakan energi metabolis merupakan energi tercerna yang dikurangi dengan energi yang keluar melalui urin (Sumadi, 2017) dan juga menunjukkan bahwa ternak babi grower memiliki kemampuan metabolis yang sama dalam mencerna energi bruto yang tersedia dalam pakan cair fermentasi yang dikonsumsi.

\section{KESIMPULAN}

Disimpulkan bahwa kandungan energi (energi bruto, energi tercerna, dan energi metabolis) pakan cair fermentasi berbahan biji asam dipengaruhi oleh lama fermentasi. Kandungan energi mengalami peningkatan hingga lama fermentasi 14 hari dan mengalami penurunan jika lama fermentasi ditingkatkan menjadi 21 dan 28 hari, serta kandungan energi (energi bruto, energi tercerna, dan energi metabolis) terbaik pada lama waktu fermentasi 14 hari yakni $4.835 \pm 64,74 \quad \mathrm{Kkal} / \mathrm{kg}$, $3.041 \pm 99,16 \mathrm{Kkal} / \mathrm{kg}$, dan $2.974 \pm 99,60$ $\mathrm{Kkal} / \mathrm{kg}$.

\section{UCAPAN TERIMAKASIH}

Penulis mengucapkan terimakasih kepada institusi Politeknik Pertanian Negeri Kupang atas pemberian dana hibah PNBP sehingga penelitian ini bisa terlaksana dengan baik.

\section{DAFTAR PUSTAKA}

Aini N, Wijonarko G dan Sustriawan B. 2016. Sifat Fisik, Kimia, dan Fungsional Tepung Jagung Yang Diproses Melalui Fermentasi. Jurnal Agritech. 36 (2): 160-169.

Azizah N, Al-Baari AN dan Mulyani S. 2012. Pengaruh Lama Fermentasi terhadap Kadar alkohol, pH, dan Produksi Gas Pada Proses Fermentasi Bioethanol dari Whey Dengan Subtitusi Kulit Nanas. Jurnal Aplikasi Teknologi Pangan. 1 (2) : 72-77.

Badan Standardisasi Nasional, 2006. Pakan Babi Pembesaran (Pig Grower). SNI 013913-2006.

Desmiaty Y, Ratih H, Dewi MA dan Agustin R. 2008. Penentuan Jumlah Tanin Total pada Daun Jati Belanda (Guazuma ulmifolia Lamk) dan Daun Sambang Darah 
(Excoecaria bicolor Hassk.) Secara Kolorimetri dengan Pereaksi Biru Prusia. Ortocarpus. 8: 106-109.

Despal, Permana IG, Safarina SN dan Tatra AJ. 2011. Penggunaan Berbagai Sumber Karbohidrat Terlarut Air untuk Meningkatkan Kualitas Silase Daun Rami. Media Peternakan. 34 (1): 69-76.

Gomez KA dan Gomez AA. 2010. Statistical Procedures for Agricultural Research (Prosedur Statistik Untuk Penelitian Pertanian Alih Bahasa oleh E. Syamsuddin dan J. S. Babarsyah). Edisi Kedua. UI Press. Jakarta.

Hartawan M. 2007. Perubahan Mikrobiologis Selama Fermentasi Bebontot. Majalah Ilmiah Peternakan. 10 (2): 1040-1053

Lestari MW, Bintoro VP dan Rizqiati H. 2018. Pengaruh Lama Fermentasi Terhadap Tingkat Keasaman, Viskositas, Kadar Alkohol, dan Mutu Hedonik Kefir Air Kelapa. Jurnal Teknologi Pangan. 2 (1): 813.

May RW and Bell JM. 1971. Digestible and Metabolizable Energy Values of Some Feeds for The Growing Pig. Canadian J. Anim. Sci. 51 (2) : 271-278.

Noblet J and Perez JM. 1993. Prediction of Digestibility of Nutrients and Energy Vlalues of Pig Diets From Chemical Analysis. J. Anim. Science. 7: 3389-3398.
Panigrahi S, Bland B and Carlaw PM. 1989. The nutritive value of tamarind seeds for broiler chicks. Animal Feed Science and Technology. 22 (4): 285-293.

Sumadi IK. 2017. Ilmu Nutrisi Ternak Babi. Fakultas Peternakan Universitas Udayana Denpasar. https://simdos.unud.ac.id/ uploads/file_pendidikan_1_dir/bb14ef3cfe 5cb8247900aed1768b2947.pdf Diunduh tanggal 25 September 2020.

Wea R, Balle-Therik JF, Kalle PR and. Mulik ML. 2019. Effect of Length of Soaking and Fermentation Using Palm Juice onNutrient Content of Tamarind Seeds. Pakistan Journal of Nutrition. 18 (8): 704-710. doi: 10.3923/pjn.2019.704.710.

Wea R. 2019. Pemanfaatan Biji Asam Terfermentasi Dalam Rangka Meningkatkan Kinerja Produksi Dan Kualitas Daging Babi Persilangan. Disertasi Pasca Sarjana Universitas Nusa Cendana Kupang.

Wea R, Ninu AY dan Koten BB. 2020. Kualitas Nutrisi dan Anti Nutrisi Pakan Cair Fermentasi Berbahan Biji Asam. Jurnal Peternakan Indonesia. 22 (2): 133-140. doi: 10.25077/jpi.22.2.133-140.2020.

Westendarp H. 2006. Effects of Tanins in Animal Nutrition. Dtsch. Tierarztl. Wochenschr. 113:264-268. 